\title{
Cardiomegaly and heart failure in a patient with prolactin-secreting pituitary tumour
}

\author{
GUGLIELMO CURTARELLI AND CARLO FERRARI \\ From the 2nd Department of Medicine, Fatebenefratelli Hospital, Milan, Italy
}

\begin{abstract}
Unexplained cardiomegaly with cardiac failure was observed in a 42-year-old woman in whom a pituitary tumour had been treated by radiotherapy five years previously. She had been amenorrhoeic for 10 years. Thyroid and adrenal function was normal. Despite treatment with digitalis and diuretic, her cardiac disease progressed until she died suddenly at the age of 45 . Hyperprolactinaemia was evident some weeks before death, her serum concentration of $68 \mathrm{ng} / \mathrm{ml}$ being well above both the reported normal range $(2-20 \mathrm{ng} / \mathrm{ml})$ and the concentrations in eight female controls being treated for severe cardiac failure $(5-25 \mathrm{ng} / \mathrm{ml})$. Although the association of these two disorders might merely represent coincidence, heart disease with similar features is common in acromegaly and does not correlate with plasma growth hormone concentration. Since prolactin is known to exert metabolic growth hormone-like effects in animals and in man, the possibility should be considered that prolactin hypersecretion might induce or maintain cardiac disease in some patients with pituitary tumours. A preliminary survey of 35 subjects with hyperprolactinaemia has shown five with raised blood pressure and four, two of whom were normotensive, with cardiomegaly on chest radiographs.
\end{abstract}

Cardiomegaly is an almost uniform finding in acromegalic patients (Daughaday, 1968). Cardiovascular disorders have often been associated with acromegaly (see McGuffin et al, 1974, for review) and represent the main cause of death in this disease (Wright et al, 1970). Though in most cases known aetiological factors of heart disease, such as hypertension, diabetes mellitus, coronary atherosclerosis, or sometimes hyperthyroidism, had been present, patients with unexplained cardiomyopathy have been described (McGuffin et al, 1974), and the existence of a specific acromegalic cardiomyopathy has been suggested (Pepine and Aloia, 1970; Joplin and Lewis, 1973). The incidence of cardiac failure, however, has been reported to increase rather than decrease after effective treatment of acromegaly (Hamwi et al, 1960), and a prospective study has failed to show any correlation between the plasma growth hormone concentration and the existence of cardiac disease (McGuffin et al, 1974). This has led to speculation that the cardiovascular complications of acromegaly might be due to other pituitary products (Cavalieri, 1975). We report a case of unexplained cardiomegaly and heart failure associated with prolactin hypersecretion by a pituitary tumour.

\section{Case report}

A 42-year-old white woman was admitted to the hospital in February 1974 because of dyspnoea on exertion, paroxysmal nocturnal dyspnoea, and ankle oedema for two months. Menarche had occurred at the age of 16 and the patient had been oligomenorrhoeic since then. She married at the age of 28 but never became pregnant. From the age of 32 the patient had been amenorrhoeic. In the next 10 years she noticed weight gain of some $30 \mathrm{~kg}$ and complained of headache of progressively increasing severity. When aged 37 pituitary tumour was diagnosed by air encephalography, and she was treated with telecobalt treatment with remission of her headache. No visual field impairment had occurred either before or after treatment, and she had been well until two months before admission. She was overweight (height $153 \mathrm{~cm}$, weight $69 \mathrm{~kg}$ ) but not dyspnoeic at rest; pulse was 88 , regular and blood pressure $140 / 80 \mathrm{mmHg}$; the liver was palpable $3 \mathrm{~cm}$ below the costal margin, and there was ankle oedema. There was no galactorrhoea. A chest radiograph showed massive cardiac enlargement and pulmonary stasis (see figure). The electrocardiogram suggested moderate left ventricular hypertrophy and 


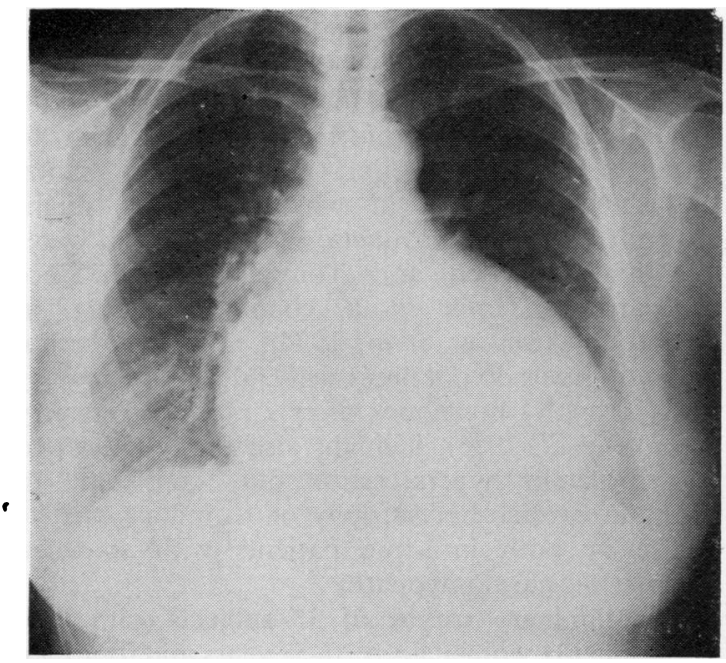

Chest radiograph of patient on first hospital admission.

showed ST-T changes in left ventricular leads; isolated ventricular ectopic beats were also present. A skull radiograph confirmed the existence of an enlarged sella with a very thin dorsum. Endocrinological evaluation showed normal serum thyroxine $(6 \cdot 1 \mu \mathrm{g} / 100 \mathrm{ml})$ and resin triiodothyronine uptake as evaluated by a competitive protein binding radioassay, a slightly raised ${ }^{131}$ I thyroid uptake $(9$, 22 , and 54 , and $67 \%$ at $2,6,24$, and $48 \mathrm{~h}$ respectively) with a normal PB ${ }^{131}$ I $(0.09 \%$ of the administered dose per litre of plasma) and thyroid scintiscan. Serum radioimmunoassayable thyrotrophin was normal at $1.4 \mu \mathrm{U} / \mathrm{ml}$ with a peak of $29 \cdot 3 \mu \mathrm{U} / \mathrm{ml}$ and a slow decline after intravenous injection of thyrotrophin-releasing hormone $(200 \mu \mathrm{g})$. Plasma fluorogenic corticosteroids $(10.4 \mu \mathrm{g} / 100 \mathrm{ml})$ and urinary Porter-Silber chromogens $(3.8 \mathrm{mg} / 24 \mathrm{~h})$ were also normal. Serum growth hormone was normal at $0.8 \mathrm{ng} / \mathrm{ml}$ and did not increase above this level during a four-hour oral glucose tolerance test. Serum gonadotrophins were within the normal range (follicle-stimulating hormone, $14 \cdot 1 \mathrm{mIU} / \mathrm{ml}$; luteinising hormone, $25 \mathrm{mIU} / \mathrm{ml}$ ). Serum prolactin determination was not available in this institution at that time. Oral glucose tolerance, serum cholesterol, triglycerides, sodium, potassium, calcium, phosphorus, urea nitrogen, and creatinine were normal. Cardiomyopathy was suggested on cardiac catheterisation by finding raised wedge pressure and left ventricular end-diastolic pressure with no valvular gradients or shunts. She was discharged from the hospital and started digoxin and frusemide treatment. In May 1975, having been relatively well for over a year, she was again admitted because high blood pressure had been discovered during a follow-up visit. Her blood pressure was now 150/120 $\mathrm{mmHg}$; physical examination found no signs of cardiac failure. On the following days in hospital blood pressure was recorded as $140 / 95 \mathrm{mmHg}$ or less. Renal function was normal as judged by serum chemistry, glomerular filtration rate, and radioisotope renogram; plasma renin activity was normal at $1 \cdot 14 \mathrm{ng} / \mathrm{ml} / \mathrm{h}$. The electrocardiogram showed worsened signs of left ventricular hypertrophy and ST-T changes with inverted $T$ waves in left ventricular leads. Her heart was no larger than on the first hospital admission. When discharged she was taking digoxin and frusemide and she remained well until January 1977, when she complained again of dyspnoea on exertion and at rest. Chest radiograph showed further cardiac enlargement with left cardiac profile at the chest wall. In March 1977 she was admitted with pulmonary oedema and was treated with ouabain and frusemide. Blood pressure was $140 / 90 \mathrm{mmHg}$. The electrocardiogram showed worsened signs of coronary insufficiency. After eight days in hospital the patient was relatively well on digoxin and frusemide. Blood was taken next morning for hormonal determinations and she was discharged. In April 1977 she died suddenly at home: necropsy was not performed.

On the last admission, serum thyroxine was 4.4 $\mu \mathrm{g} / 100 \mathrm{ml}$ (normal, $3 \cdot 5-12 \cdot 5$ ), resin triiodothyronine uptake was 98.7\% (normal, 92-117), and free thyroxine index was $4 \cdot 46$ (normal, $3 \cdot 5-12 \cdot 5$ ); serum triiodothyronine was $120 \mathrm{ng} / 100 \mathrm{ml}$ (normal, 70-180); serum thyrotrophin was 5.9 $\mu \mathrm{U} / \mathrm{ml}$ (normal, <1-4.5); serum growth hormone was 1.8 $\mathrm{ng} / \mathrm{ml}$ (normal, <1-5); and serum prolactin was 68 $\mathrm{ng} / \mathrm{ml}$ (mean of two samples taken at 30 minuteinterval; normal values, $2-20 \mathrm{ng} / \mathrm{ml}$ ). The mean serum prolactin concentration in eight women with pulmonary oedema treated with ouabain and frusemide who were studied as controls was $10.7 \mathrm{ng} / \mathrm{ml}$ (range, $5-25 \mathrm{ng} / \mathrm{ml}$ ).

\section{Discussion}

The case history of this patient resembles very closely some reported cases of acromegalic heart disease (Pepine and Aloia, 1970; Joplin and Lewis, 1973; McGuffin et al, 1974). While it is interesting that cardiac decompensation has been reported in patients with very mild acromegaly and in patients in whom growth hormone secretion had been normalised or even impaired by successful treatment (Hamwi et al, 1960; Joplin and Lewis, 1973; McGuffin et al, 1974), our patient had no history or clinical features of acromegaly, and her serum growth hormone concentration was re- 
peatedly normal when she came to our attention. She had been oligomenorrhoeic and infertile until the age of 32, when she became amenorrhoeic; subsequently, suggestive symptoms of intracranial hypertension led to the diagnosis of pituitary tumour. Five years after successful radiotherapy she developed cardiac failure. One year later she presented with moderate and unstable hypertension. Two years later hyperprolactinaemia was finally, though tardily, found. The raised prolactin concentrations found in the patient do not seem to be related to stress factors or to drug treatment, since the serum prolactin concentration did not exceed $25 \mathrm{ng} / \mathrm{ml}$ in eight women with severe circulatory failure studied as controls during treatment with ouabain and frusemide. Since hyperprolactinaemia is common in patients with "functionless" pituitary tumours (Snyder et al, 1974), especially in women presenting with hypogonadism without other endocrine dysfunction (Child et al, 1975), the patient probably had long-standing prolactin hypersecretion from a pituitary tumour, which was maintained after radiotherapy either by residual adenomatous cells or by interference with the hypothalamic inhibitory control mechanism of prolactin secretion. The patient had no known aetiological factors of heart disease, including rheumatic disease, hypertension, thyrotoxicosis or hypothyroidism, diabetes mellitus, hyperlipidaemia, smoking, or alcohol consumption.

The coexistence of hyperprolactinaemia and heart disease in this woman might merely represent coincidence, since such an association has not previously been recognised. Detailed studies, however, of the cardiovascular system in functionless pituitary tumours have not been reported, and serum prolactin determination has only recently become available. The possibility that prolactin hypersecretion might lead to heart disease must therefore be considered. Prolactin is structurally closely related to growth hormone (Wallis and Davies, 1976), possesses growth-promoting activity in animals (Nicoll and Bern, 1972), and exerts growth hormone-like metabolic effects in man, including nitrogen retention, increased calcium excretion, impairment of glucose tolerance, fat mobilisation, and even skeletal growth (McGarry and Beck, 1972; Berle et al, 1974; Landgraf et al, 1977). Moreover, growth hormone and prolactin bind to one common receptor in rat liver cell membranes (Posner et al, 1974) and in human lymphocytes (Lesniak et al, 1977); somatomedin generation has been found in rat liver after perfusion with ovine prolactin (Francis and Hill, 1975); prolactin has been shown to increase serum somatomedinlike activity and to promote growth in hypopituitary dwarf mice (Holder and Wallis, 1977).
Cardiomyopathy (MacDonald et al, 1972) and $\vec{\Rightarrow}$ sudden death (Leestma and Koenig, 1968) have been $\stackrel{5}{+}$ reported in some patients on chronic treatment with 읃 large doses of phenothiazines, drugs known to stimulate prolactin secretion (Kleinberg and Frantz, $\frac{\mathscr{T}}{\sigma}$ 1971). Another way in which prolactin might $\stackrel{\AA}{\complement}$ disturb cardiovascular function is sodium and water $\stackrel{\infty}{\infty}$ retention (Hanssen and Torjesen, 1977). Since $\vec{\circ}$ hyperprolactinaemia is a common finding in acromegaly (Snyder et al, 1974), and since serum $\vec{\omega}$ prolactin levels do not necessarily fall simultaneously with growth hormone after pituitary surgery $\vec{x}$ (Franks et al, 1976), it might also be hypothesised $\omega_{\vec{\omega}}$ that prolactin hypersecretion may contribute to $\dot{\omega}$ maintain cardiac hypertrophy or to induce cardiac $\omega$ failure or both in some patients with so-called $\infty$ acromegalic cardiomyopathy.

A preliminary survey of 35 subjects with pro- lactinoma (31 women aged $20-58$ years and four men $\subseteq$ aged 30-42 years) admitted to the department of $\frac{\bar{D}}{\vec{D}}$ neurosurgery of the University of Milan showed the $\vec{\oplus}$ existence of raised blood pressure levels (systolic values greater than 160 , diastolic greater than 95 $\mathrm{mmHg}$ ) in five cases (four women aged 24-50 and one man aged 39); cardiomegaly was found on the chest radiographs of the two patients who had diastolic blood pressure levels greater than $110 \stackrel{0}{\circ}$

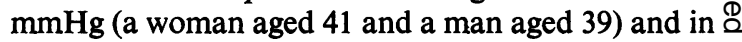
two normotensive women aged 30 and 58 who had $\overrightarrow{\overrightarrow{0}}$ had symptoms suggestive of a pituitary tumour for 3 15 and 24 years respectively. Although the prevalence of hypertension in these patients may thus? not differ from that found in the general population, the finding of cardiomegaly in the absence of any 을 known aetiological factors of heart disease in some $\ddot{x}$ patients with long-standing prolactinoma is of $\frac{0}{3}$ interest, especially as the mean duration of pituitary disease in the entire series was estimated to be only $6 \cdot 8 \pm 0.9$ (SE) years by the time the first endocrine or $₹$ neurological symptoms occurred. Prospective studies 의 are obviously needed to evaluate the incidence of heart disease in hyperprolactinaemic subjects and the possible role of prolactin in the pathogenesis of $\bar{N}$ cardiovascular disorders associated with pituitary tumours. surgery, University of Milan, for permission to review the records of his patients.

\section{References}

Berle, P, Finsterwalder, E, and Apostolakis, M (1974). $\frac{\vec{C}}{\mathbb{D}}$ Comparative studies on the effect of human growth hormone, human prolactin and human placental $\$$ lactogen on lipid metabolism. Hormone and Metabolic Research, 6, 347-350. 
Cavalieri, R L (1975). Acromegaly and cardiovascular disease. Annals of Internal Medicine, 82, 429-430.

Child, D F, Nader, S, Mashiter, K, Kjeld, M, Banks, L, and Fraser, T R (1975). Prolactin studies in "functionless" pituitary tumours. British Medical Journal, 1, 604-606.

Daughaday, W H (1968). The adenohypophysis. In Textbook of Endocrinology, edited by $\mathbf{R} \mathbf{H}$ Williams, 4th edn, pp 27-84. Saunders, Philadelphia.

Francis, M J, and Hill, D J (1975). Prolactin-stimulated production of somatomedin by rat liver. Nature, 255 , 167-168.

Franks, S, Jacobs, H S, and Nabarro, J D N (1976). Prolactin concentrations in patients with acromegaly: clinical significance and response to surgery. Clinical Endocrinology, 5, 63-69.

Hamwi, G J, Skillman, T G, and Tufts, K C (1960). Acromegaly. American Journal of Medicine, 29, 690-699.

Hanssen, K F, and Torjesen, P A (1977). Increased serum prolactin in diabetic ketoacidosis; correlation between serum sodium and serum prolactin concentration. Acta Endocrinologica, 85, 372-378.

Holder, A T, and Wallis, M (1977). Actions of growth hormone, prolactin and thyroxine on serum somatomedin-like activity and growth in hypopituitary dwarf mice. Journal of Endocrinology, 74, 223-229.

Joplin, G F, and Lewis, P (1973). A case of acromegalic heart disease. British Medical Journal, 1, 718-724.

Kleinberg, D L, and Frantz, A G (1971). Human prolactin: measurement in plasma by in vitro bioassay. Journal of Clinical Investigation, 50, 1557-1568.

Landgraf, R, Landgraf-Leurs, M M C, Weissmann, A, Hörl, R, von Werder, K, and Scriba, P C (1977). Prolactin: a diabetogenic hormone. Diabetologia, 13, 99-104.

Leestma, J E, and Koenig, K L (1968). Sudden death and phenothiazines. Archives of General Psychiatry, 18, 137-144.

Lesniak, M A, Gorden, P, and Roth, J (1977). Reactivity of non-primate growth hormones and prolactins with human growth hormone receptors on cultured human lymphocytes. Journal of Clinical Endocrinology and Metabolism, 44, 838-849.
McDonald, C D, Burch, G E, and Walsh, J J (1972). Prolonged bed rest in the treatment of idiopathic cardiomyopathy. American Journal of Medicine, 52, 41-50.

McGarry, E E, and Beck, J C (1972). Biological effects of non-primate prolactin and human placental lactogen, in Lactogenic Hormones, edited by $\mathrm{G} E \mathrm{~W}$ Wolstenholme and J Knight, pp 361-368. Churchill Livingstone, Edinburgh and London.

McGuffin, W L, Sherman, B M, Roth, J, Gorden, P, Kahn, C R, Roberts, W C, and Frommer, P L (1974). Acromegaly and cardiovascular disorders. A prospective study. Annals of Internal Medicine, 81, 11-18.

Nicoll, C S, and Bern, H A (1972). On the action of prolactin among the vertebrates: is there a common denominator?, in Lactogenic Hormones, edited by G E W Wolstenholme and J Knight, pp 299-312. Churchill Livingstone, Edinburgh and London.

Pepine, C J, and Aloia, J (1970). Heart muscle disease in acromegaly. American Journal of Medicine, 48, 530-534.

Posner, B I, Kelly, P A, Shiu, R P C, and Friesen, H G (1974). Studies of insulin, growth hormone and prolactin binding: tissue distribution, species variation and characterization. Endocrinology, 95, 521-531.

Snyder, P J, Jacobs, L S, Rabello, M M, Sterling, F H, Shore, $R$ N, Utiger, R D, and Daughaday, W H (1974). Diagnostic value of thyrotrophin-releasing hormone in pituitary and hypothalamic diseases: assessment of thyrotrophin and prolactin secretion in 100 patients. Annals of Internal Medicine, 81, 751-757.

Wallis, M, and Davies, R V (1976). Studies on the chemistry of bovine and rat growth hormone, in Growth Hormone and Related Peptides, edited by A Pecile and E E Müller, pp 1-13. Excerpta Medica International Congress Series No 381, Amsterdam.

Wright, A D, Hill, D M, Lowy, C, and Fraser, T R (1970). Mortality in acromegaly. Quarterly Journal of Medicine, 39, 1-16.

Requests for reprints to: G Curtarelli, M D, 2nd Department of Medicine, Fatebenefratelli Hospital, 23 Corso di Porta Nuova, 20121 Milano. 